\title{
Uji Toksisitas Akut dan Gambaran Histopatologi Hepar Mencit yang Diberi Ekstrak Terpurifikasi Daun Galing (Cayratia trifolia L. Domin)
}

\author{
Muhammad Ilyas Yusuf ${ }^{1,2^{*}}$, Randa Wulaisfan ${ }^{3}$, Haswika $^{3}$, Wahyuni ${ }^{1}$ \\ ${ }^{1}$ Fakultas Farmasi Universitas Halu Oleo, Kampus Hijau Bumi Tridharma Anduonohu Kendari 93232 \\ ${ }^{2}$ Akademi Analis Kesehatan Bina Husada Kendari, Jl. Sorumba no. 17 Kendari, 93117 \\ ${ }^{3}$ Akademi Farmasi Bina Husada Kendari, Jl. Sorumba No.17 Kendari, 93117
}

\begin{abstract}
Abstrak
Daun galing memiliki manfaat sebagai antidiabetik, hepatoprotektor, menurunkan kadar kolesterol dalam darah, meningkatkan kekebalan tubuh, sebagai antioksidan, antivirus, antibakteri dan antikanker. Keamanan adalah suatu syarat penting yang harus dimiliki suatu obat, oleh karena itu perlu dilakukan uji untuk mengetahui keamanan pemanfaatan daun galing perlu diteliti. Tujuan penelitian ini adalah untuk mengetahui $\mathrm{LD}_{50}$ ekstrak terpurifikasi daun galing dan mengetahui gambaran histopatologi hepar mencit setelah pemberian ekstrak terfurifikasi daun galing. Penelitian ini adalah penelitian ekperimental, dengan rancangan Post test only controlled group design yang terdiri dari 5 kelompok perlakuan, terdiri dari kelompok kontrol negatif yang diberi Na CMC 0,5\%, kelompok perlakuan yang diberi ekstrak terpurifikasi daun galing $50 \mathrm{mg} / \mathrm{kgBB}, 500 \mathrm{mg} / \mathrm{kgBB}, 5.000 \mathrm{mg} / \mathrm{kgBB}$ dan $50.000 \mathrm{mg} / \mathrm{kgBB}$, tiap kelompok perlakuan yang terdiri atas 4 ekor mencit . Hasil penelitian menunjukkan ekstrak terpurifikasi daun galing bersifat sangat toksik berdasarkan klasifikasi toksisitas dengan nilai $\mathrm{LD}_{50}$ 499,9 mg/kgBB, dengan gambaran histopatologi hepar mencit pada kelompok perlakuan ekstrak dosis 5.000 dan $50.000(\mathrm{mg} / \mathrm{kgBB})$ menunjukkan adanya kerusakan sel hepar, sedangkan pada kelompok perlakuan dosis 50, $500(\mathrm{mg} / \mathrm{kgBB})$ dan kontrol negatif tidak mengalami kerusakan (nekrisis) sel hepar.
\end{abstract}

Kata Kunci: Daun galing, purifikasi, histopatologi hepar, toksisitas, mencit

\section{Pendahuluan}

Penggunaan obat tradisional di Indonesia merupakan bagian dari budaya bangsa dan banyak dimanfaatkan oleh masyarakat, namun efektivitas dan keamanannya belum sepenuhnya didukung oleh penelitian. Sumber daya alam obat tradisional merupakan aset nasional yang perlu digali, diteliti, dikembangkan dan dioptimalkan pemanfaatannya [9].

Salah satu tumbuhan di Indonesia yang dijadikan sebagai obat tradisional adalah tumbuhan galing (Cayratia trifolia L. Domin) berkhasiat sebagai antidiabetik, hepatoprotektor, menurunkan kadar kolesterol dalam darah, meningkatkan kekebalan tubuh, sebagai antioksidan, antivirus, antibakteri, dan antikanker [8]. Keamanan adalah syarat penting yang harus dimiliki oleh obat herbal. Uji toksisitas penting bagi perkembangan obat baru sebelum dapat digunakan

${ }^{*}$ KBK Farmakologi dan Farmasi Klinik Fakultas Farmasi UHO

Email: ilyasyusufmuhammad.apt $@$,gmail.com bagi manusia. Uji toksisitas dilakukan untuk menentukan bahaya atau resiko dari suatu substansi [1].

Pengujian toksisitas akut terhadap daun tumbuhan galing dengan hewan uji mencit dipilih karena sebelumya telah dilakukan uji toksisitas akut daun tumbuhan galing menggunakan metode BSLT (Brine Shrimp Lethality Test) dengan hewan uji larva udang (Artemia salina Leach) menunjukan hasil nilai $\mathrm{LD}_{50}$ dari ekstrak daun galing sebesar $405,4 \mu \mathrm{g} / \mathrm{mL}$ [2]. Namun dalam penelitian tersebut masih menggunakan ekstrak etanol daun galing, dimana pada ekstrak tersebut masih mengandung zat pengotor seperti lemak, klorofil, resin, protein dan karbohidrat yang dapat mengganggu bahan alam dalam menghasilkan aktivitas biologi [16]. Sampai saat ini informasi ilmiah tentang uji tosisitas akut dan histopatologi organ hepar pada hewan uji mencit oleh ekstrak purifikasi daun galing belum banyak diteliti, 
sehingga dilakukan penelitian lebih lanjut mengenai toksisitas dari daun galing.

\section{Metode}

\subsection{Umum}

Jenis penelitian yang digunakan adalah penelitian eksperimen, dengan desain penelitian Post-test only controlled group design dengan menggunakan 20 ekor mencit. Sampel daun galing diperoleh dari wilayah Kelurahan Anduonohu Kecamatan Poasia Kota Kendari. Penelitian ini dilakasanakan di Laboratorium Farmakologi Akademi Farmasi Bina Husada dan Laboratorium Patologi Anatomi Rumah Sakit Aliyah Kendari.

\subsection{Preparasi Sampel dan Ekstraksi}

Sampel daun galing dibersihkan, dikeringkan dan diekstraksi dengan metode maserasi menggunakan pelarut etanol $96 \%$ selama 3 hari. Ekstrak cair dikentalkan dengan menggunakan rotavapor, kemudian ekstrak dipurifikasi dengan menggunakan $n$-heksana. Lapisan $n$-heksana dipisahkan, dan dilakukan pengulangan purifikasi ekstrak sampai fase $n$-heksana berwarna bening. Fase etanol yang diperoleh selanjutnya dipekatkan dengan waterbath.

\subsection{Pengujian Toksisitas Akut}

Hewan coba dibagi dalam 5 kelompok yaitu,

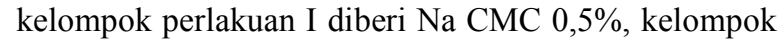
perlakuan II diberi ekstrak $50 \mathrm{mg} / \mathrm{kgBB}$, kelompok perlakuan III diberi ekstrak $500 \mathrm{mg} / \mathrm{kgBB}$, kelompok perlakuan IV diberi ekstrak $5.000 \mathrm{mg} / \mathrm{kgBB}$, dan kelompok perlakuan V diiberi ekstrak $50.000 \mathrm{mg} / \mathrm{kgBB}$. Perlakuan pada hewan uji selama 7 hari secara peroral 1 kali sehari. Sebelum dilakukan perlakuan, hewan uji dipuasakan terlebih dahulu selama 6-8 jam dengan tetap diberi minum atlibitum.

\subsection{Pemeriksaan Histopatologi Organ Hati}

Hewan uji mencit dari tiap kelompok dianestesi dengan kloroform kemudian dilakukan pembedahan pad ahari ke delapan. Organ hepar yang diperoleh kemudian ditimbang dan diukur volumenya, dan dimasukkan ke dalam wadah yang berisi formalin 10\% untuk kemudian diamati histopatologinya.

\subsection{Analisis Data}

Data yang diperoleh diolah dengan menggunakan rumus perhitungan $\mathrm{LD}_{50}$ dengan metode perhitungan menurut Thomson dan Weill (1952) [15].

\section{Hasil dan Pembahasan}

Simplisia kering diekstraksi dengan menggunakan metode maserasi. Metode maserasi dipilih karena penyariannya yang sederhana mudah dilakukan dan cocok untuk sampel yang lunak [17]. Pelarut yang digunakan adalah etanol 96\% karena bersifat universal, tidak bersifat toksik, dan tidak mudah mengurai senyawa zat aktif dari tanaman tersebut [18].

Pengujian toksisitas akut dilakukan untuk menentukan efek toksik suatu senyawa yang akan terjadi dalam masa pemejanan dengan waktu yang singkat [12]. Metode Thomson dan Weil dipilih karena tingkat kepercayaan yang cukup tinggi, metode yang sering digunakan karena tidak memerlukan hewan percobaan yang banyak [12]. Penelitian ini menggunakan 20 ekor mencit yang dibagi dalam 5 kelompok perlakuan. Pada kontrol negatif diberikan $\mathrm{Na} \mathrm{CMC} 0,5 \%$ karena $\mathrm{Na} \mathrm{CMC}$ merupakan senyawa yang tidak toksik dan tidak menimbulkan iritan [13].

Pengujian toksisitas akut ekstrak terpurifikasi daun galing pada hewan uji mencit dilakukan selama 7 hari karena kerusakan hepar dapat terjadi beberapa minggu sampai beberapa bulan setelah terkena paparan zat toksik [3]. Hasil dari perhitungan $\mathrm{LD}_{50}$ ekstrak terpurifikasi daun galing sebesar 499,9 mg/kgBB yang dikategorikan sebagai zat yang sangat toksik. Efek toksik yang ada pada ekstrak terpurifikasi daun galing disebabkan karena kandungan senyawa metabolit sekunder tanaman tersebut, seperti alkaloid, steroid dan saponin. Metabolit sekunder yang diduga dapat menyebabkan kerusakan sel adalah saponin dan alkaloid. Saponin dapat menimbulkan hemolisis sel darah merah sehingga dapat mengganggu lingkungan ekstra sel dari sel hepatosit. Sementara alkaloid juga memiliki sifat toksik karena memerlukan waktu yang lama untuk dapat diekskresikan dan dimetabolisme, sehingga kontak alkaloid dengan sel-sel hati menjadi lebih lama dan merusak hati [11].

Setelah dilakukan pemeriksaan makroskopik, organ hepar dibuat preparat histologi dengan pewarnaan Hemotoksilin-Eosin. Tahap pembuatan preparat meliputi proses fiksasi dimana organ hepar yang telah diambil dimasukkan kedalam larutan formalin $10 \%$ dengan tujuan untuk mempertahankan susunan jaringan serta mengeraskan jaringan agar memudahkan pengirisan sehingga agar organ hepar tidak mengalami pembusukan dan kerusakan jaringan hepar [6]. Setelah itu dilakukan cut up pada sampel, kemudian tahap selanjutnya dehidrasi tujuan dari tahapan ini adalah untuk menghilangkan cairan yang terdapat dalam jaringan yang telah difiksasi. Clearing dilakukan untuk membersihkan jaringan dengan menggunakan larutan yang dapat berikan dengan parafin [6]. 

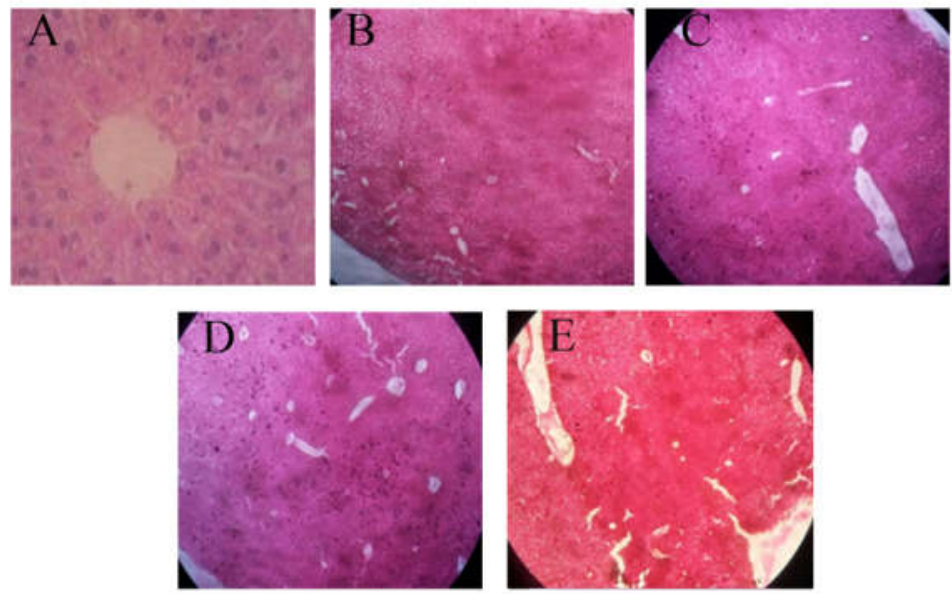

Gambar 1. Hispatologi hepar mencit Gambaran histopatologi hepar mencit yang diberikan. $\mathbf{A}=(\mathrm{Na} \mathrm{CMC} 0,5 \%) ; \mathbf{B}=($ Ekstrak 50 $\mathrm{mg} / \mathrm{kgBB}) ; \mathbf{C}=($ Ekstrak $500 \mathrm{mg} / \mathrm{kgBB}) ; \mathrm{D}=($ Ekstrak $5.000 \mathrm{mg} / \mathrm{kgBB}) ; \mathbf{E}=($ Ekstrak $50.000 \mathrm{mg} / \mathrm{kgBB}) ; \rightarrow$ Vena sentral; $\rightarrow$ Inti sel; $\rightarrow$ Sinusoid; $\rightarrow$ Nekrosis.

Selanjutnya dilakuan blocking proses ini dilakukan agar preparat dapat dipotong dengan mikrotom, kemudian dilakukan sectioning dengan mikrotom. Staining merupakan proses pemberian warna pada jaringan yang telah dipotong sehingga jaringan dapat diamati di mikroskop. Pewarna Hemotoksilin memberikan warna biru pada inti sel sedangkan Eosin memberikan warna merah pada sitoplasma [6].

Hasil pengamatan mikroskopik gambaran histopatologi sel hepar mencit setelah perlakuan selama 7 hari dapat ditunjukkan pada gambar 1. Perlakuan A menunjukkan gambaran histologi sel hepar yang terlihat masih normal. Hal ini ditandai dengan sel-sel hepatosit masih tersebar rata, inti sel bulat di tengah, padat dan batas sel (sinusoid) masih terlihat jelas serta vena sentral tidak mengalami kongesti atau pembendungan darah [5]. Pada perlakuan B menunjukkan gambaran histopatologi sel hepar mengalami kerusakan. Hal ini ditandai dengan terjadi degenerasi dimana terjadi pembengkakan pada sitoplasma. Degenerasi merupakan tanda awal kerusakan hepar akibat toksin yang bersifat sementara dan sel masih bisa pulih atau normal kembali apabila paparan toksin dihentikan [4]. Sinusoid pada perlakuan ini masih terlihat jelas tetapi arahnya sudah tidak bermuara ke vena sentral. Vena sentral mengalami kongesti, kerusakan ini terjadi karena terlalu banyak darah yang masuk ke arteri atau terlalu kecilnya darah yang menuju vena. Secara mikroskopis kongesti ditandai dengan adanya dilatasi pada dinding arteri yang disebabkan oleh banyaknya volume darah pada bagian tersebut [7]. Perlakuan C menunjukkan gambaran histopatologi sel hepar mengalami kerusakan. Hal ini ditandai terjadi degenerasi dimana terjadi pembengkakan pada sitoplasma. Degenerasi merupakan tanda awal kerusakan hepar akibat toksin yang bersifat sementara dan sel masih bisa pulih atau normal kembali apabila paparan toksin dihentikan [4].

Sinusoid pada perlakuan ini masih terlihat jelas tetapi arahnya sudah tidak bermuara ke vena sentral. Vena sentral mengalami kongesti, kerusakan ini terjadi karena terlalu banyak darah yang masuk ke arteri atau terlalu kecilnya darah yang menuju vena. Secara mikroskopis kongesti ditandai dengan adanya dilatasi pada dinding arteri yang disebabkan oleh banyaknya volume darah pada bagian tersebut [7].

Pada perlakuan D menunjukkan gambaran histopatologi sel hepar mengalami kerusakan (nekrosis), hal ini ditandai dengan inti sel tidak terlihat karena telah mengalami nekrosis ditandai dengan ciri-ciri nukleus mengkerut (piknosis), nukleus pecah (kariokinesis), nukleus lisis (kariolisis), membran sel mengalami lisis sehingga menimbulkan ruang-ruang kosong. Sinusoid antara sel tidak nampak jelas [5]. Vena sentral mengalami kongesti, kerusakan ini terjadi karena terlalu banyak darah yang masuk ke arteri atau terlalu kecilnya darah yang menuju vena. Secara mikroskopis kongesti ditandai dengan adanya dilatasi pada dinding arteri yang disebabkan oleh banyaknya volume darah pada vena sentral [7]. Perlakuan $\mathbf{E}$ menunjukkan gambaran histopatologi sel hepar mengalami kerusakan (nekrosis), hal ini ditandai inti sel tidak terlihat serta batas sel yang tidak jelas karena telah mengalami nekrosis yang ditandai dengan ciri-ciri nukleus mengkerut (piknosis), nukleus pecah (kariokinesis), nukleus lisis (kariolisis), membran sel mengalami lisis sehingga batas antara sel tidak nampak jelas [5]. Vena sentral mengalami kongesti, kerusakan ini terjadi karena terlalu banyak 
darah yang masuk ke arteri atau terlalu kecilnya darah yang menuju vena. Secara mikroskopis kongesti ditandai dengan adanya dilatasi pada dinding arteri yang disebabkan oleh banyaknya volume darah pada vena sentral [7].

Hasil gambaran histopatologi yang diberikan $\mathrm{Na}$ CMC 0,5\% yang terlihat masih normal. Hal ini ditandai dengan sel-sel hepatosit masih tersebar rata, inti sel bulat di tengah, padat dan batas sel (sinusoid) masih terlihat jelas [5]. Hasil gambaran histopatologi yang diberikan ekstrak terpurifikasi daun galing telah mengalami kerusakan. Hal ini ditandai dengan terjadinya degenerasi karena pembengkakan pada sitoplasma [4]. Inti sel tidak terlihat, serta batas sel yang tidak jelas karena telah mengalami nekrosis [5]. Vena sentral mengalami kongesti pada dinding arteri yang disebabkan oleh banyaknya volume darah pada bagian tersebut.

\section{Kesimpulan}

Berdasarkan hasil penelitian uji toksisitas akut ekstrak terpurifikasi daun galing (Cayratia trifolia L. Domin) pada hewan uji mencit, dapat disimpulkan bahwa nilai $\mathrm{LD}_{50}$ adalah $499,9 \mathrm{mg} / \mathrm{kgBB}$ kategori sangat toksik berdasarkan klasifikasi toksisitas dan berdasarkan pengamatan histopatologi organ hepar hewan uji mencit menunjukkan adanya kerusakan sel (nekrosis) pada dosis $5.000 \mathrm{mg} / \mathrm{kgBB}$ dan $50.000 \mathrm{mg} / \mathrm{kgBB}$.

\section{Daftar Pustaka}

1. Arome D, Chinedu E. The Importance of Toxicity Testing, J. Phar. BioSci., 4(2013); 146-148.

2. Febryanti, A. 2016, "Uji Toksisitas Akut Ekstrak Daun dan Batang Galing (Cayratia trifolia L.Domin) Terhadap Larva Udang (Artemia salina Leach)". Karya Tulis Ilmiah, Amd. Farm, Kendari: Akademi Farmasi Bina Husada, 2016.

3. Crawford JM. Liver and Biliary Tract. Philadelphia: Elsevier Sounders, 2005.

4. Harada T. Pathology of the Mouse: Liver and Gall Bladder. Chache River Press, 1999.

5. Hastuti US. Pengaruh Berbagai Dosis Citrinin Terhadap Kerusakan Struktur Hepatosit Mencit (Musmusculus)
Pada Tiga Zona Lobulus Hepar. Jurnal Kedokteran Brawijaya, 2006, 3;121-126

6. Jusuf AA. Histoteknik Dasar. Jakarta: FK UI, 2009.

7. Jones TS, Bodtker A, Kmitta D. Comprehensive Peer Mediation Evaluation Project, Preliminary Final Report. Philadelphia: Temple University, 1997.

8. Kumar D, Gupta J, Kumar S, Arya R, Kumar T, Gupta A. Pharmacognostic Evaluation of Cayratia trifolia (Linn.) Leaf, Asian Pacific J. of Tropical Biomed., 2012, 2;6-10.

9. Peraturan Menteri Kesehatan Republik Indonesia Nomor 88 Tahun 2013. Tentang Rencana Induk Pengembangan Bahan Baku Obat Tradisional, Jakarta: Kementerian Kesehatan Republik Indonesia, 2013.

10. Moslen NT. Toxic Responses of Liver. New York: McGraw Hill, 2001.

11. Nurqolbiah E, Kusharyanti I, dan Nurbaeti SN. Uji Toksisitas Fraksi Air Impatiens pada Tikus Betina Galur Sprague Dawley. Pharm Sci Res, 2014, 1(1);16-29.

12. Priyanto. Toksikologi Mekanisme, Terapi Antidotum, dan Penilaian Resiko. Depok: Lembaga Studi dan Konsultasi Farmakologi (Leskonfi), 2009.

13. Rowe RC, Sheykey PJ, dan Quin ME. Handbook of Pharmaceutical Exipients Sixth Edition. London: Pharmaceutical Press, 2009

14. Susanti D, Ardiana D, Gumelar GP, dan Bening YG. Polaritas Pelarut Sebagai Pertimbangan Pemilihan Pelarut Untuk Ekstraksi Bekatul Dari Bekatul Varietas Ketan (Oriza sativa glatinosa). Prosiding Simposium Nasional RAPI XI FT UMS; 2012, Surakarta. ISSN: 1412-9612; 814

15. Thompson WR, Weil CS. On The Contruction of Tables For Moving Average Interpolation, Biometrics, 1952, 8; 51-54.

16. Widyaningtias NMSR, Yustiantara PS, dan Paramitha NLPV. Uji Aktivitas Ekstrak Terpurifikasi Daun Sirih Hijau (Piper betle L.) Terhadap Bakteri Propionibacterium acnes, Jurnal Farmasi Udayana, 2014, 3(1); 50-53.

17. Departemen Kesehatan RI. Parameter Standar Umum Ekstrak Tumbuhan Obat. Jakarta: Direktorat Pengawasan Obat Tradisional, 2000.

18. Gruben GJH, Denton OA. Plant Resources of tropical Africa 2: Vegetables. Wageningen: PROTA Foundation/ Backhuys Publishers/CTA, 2004. 